\title{
A Note on the Design of Experiments Involving Public Goods
}

\author{
Philip E. Graves
}

CESIFO WORKING PAPER NO. 3187

CATEGORY 9: RESOURCE AND ENVIRONMENT ECONOMICS

SEPTEMBER 2010

\footnotetext{
An electronic version of the paper may be downloaded

- from the SSRN website: Www.SSRN.com

- from the RePEc website: Www.RePEc.org

- from the CESifo website: www.CESifo-group.org/wp
} 


\title{
A Note on the Design of Experiments Involving Public Goods
}

\begin{abstract}
Concern about potential free riding in the provision of public goods has a long history. More recently, experimental economists have turned their attention to the conditions under which free riding would be expected to occur. A model of free riding is provided here which demonstrates that existing experimental approaches fail to explore a potentially important real-world dimension of free riding. In a cash-in-advance economy, free riding becomes a two-stage problem, while existing experiments only address the second stage. That is, one would expect households with high demands for public goods relative to private goods to generate less income than households preferring ordinary private goods, because the former are unable to individually increment the public good and leisure is valuable. Existing experiments start with a given number of "tokens" for each decision-maker, effectively only addressing the second stage of the free riding problem, namely, under what conditions free riding becomes a problem out of a given income. A recommended solution to this problem is to incorporate the potential to generate income prior to (or simultaneously with) the decision of how to allocate that income between private and public goods.
\end{abstract}

JEL-Code: A10, C90, C92, D03, D12, D64, D81, H41, Q50.

Keywords: decision making, choice behavior, public goods, experimental economics, altruism, fairness, conditional reciprocity.

\author{
Philip E. Graves \\ Department of Economics UCB 256 \\ University of Colorado \\ USA - Boulder, CO 80309-0256 \\ Philip.Graves@colorado.edu
}

Revised: July 2010

I would like to acknowledge the comments on related papers of those attending seminars at the University of British Columbia, George Mason University, Colorado State University, Georgia State University, North Carolina State University, Rochester Institute of Technology, University of Chicago, University of Colorado, University of Louisville and the University of Missouri on earlier variants of this paper. I would like specifically to thank Ron Cummings, Nick Flores, Rick Freeman, Don Fullerton, John Horowitz, John List, Keith Maskus, Ted McConnell, Peter Mueser, Jack Robles, Kerry Smith, Laura Taylor, George Tolley, Donald Waldman, and Randy Walsh. Additionally, I would like to acknowledge the support of CESifo in Munich where I revised this paper. I retain responsibility for any remaining errors. 


\section{Introduction}

In an excellent recent review, Levitt and List (2007) ask "What do laboratory experiments measuring social preferences reveal about the real world?" They focus on a wide range of experimental games (ultimatum, dictator, trust, gift exchange, and public goods) that have been used to try to understand the nature of preferences in social settings. Their general conclusions are that many real-world markets operate in ways that make pro-social behavior less likely than it seems from laboratory experiments, although there are situations-notably publicized dealings among friends and family-in which pro-social behavior might be more likely in the real world than in the laboratory.

The concern here is with public goods games. It is frequently observed that the extent of free riding, from a given "token endowment," varies according to the nature of the experimental intervention, discussed more fully below. But an additional free riding problem has not been recognized — and, importantly, not been incorporated into experimental design. When incentives exist to free ride in output markets, those incentives also distort input market decisions.

In the following section, a model of free riding is presented. This model demonstrates that free riding would generally be expected in both input and output markets. In Section III, it is seen that existing experimental methods ignore half of the general problem, making extrapolation to real-world settings even more problematic than previously thought. Section IV concludes with research recommendations.

\section{Rational Public Good Free-Riding Behavior: A Simple Model}

For models of free riding behavior to be relevant to experimental analyses, they must incorporate two central observations that are really a generalization of the prisoner's dilemma. First, if an individual attempts to increment the public good, and others do not, private good losses are large relative to any gains from the public good. Second, if the other households do contribute to the public good provision, an individual household will be little damaged by failing to contribute. Both of these effects work to encourage free riding, but the extent of free riding in the laboratory or in the real world will depend on many things, including the numbers of people involved and whether decisions are "one-shot" or repeating.

Let the price of ordinary goods, $\mathrm{X}$, be the numeraire good and let $\left(1-\mathrm{L}_{\mathrm{i}}\right)$ represent the share of total time (normalized to equal 1) spent working at wage $\mathrm{W}_{\mathrm{i}}$, and $\mathrm{G}$ is the amount of public good consumed. A simple model capturing the essential nature ${ }^{1}$ of free riding for household $i$ is as follows:

1

Most models of free riding (e.g. those in Varian 1987 or Hanley, Shogren, and White 1997) do not endogenize leisure, but start with a fixed money income. This explicitly omits the present concern with free riding in input markets. 
1) $\operatorname{Max} U\left(L_{i}, X_{i}, G\right)$ subject to the budget constraint (1- $\left.L_{i}\right) W_{i}=X_{i}+p G_{i}$

$$
\text { where } G=G_{i}+\Sigma G_{j} \quad \vee j \neq i \text {. }
$$

That is, the quantity of the public good that each individual actually experiences equals what he and all other households collectively choose. Assuming a Nash equilibrium, we take $\Sigma G_{j}$ as given, so the optimization of Equation 1) reflects the sum of all individuals' choices.

While the marginal benefit of an increment to the private good is $\partial \mathrm{U}(\bullet) / \partial \mathrm{X}$, the marginal benefit of the public good is the sum of the benefits over all of the individuals, $\Sigma \partial \mathrm{U}(\bullet) / \partial \mathrm{G}, \vee$ i. Hence, from society's perspective, setting the marginal rate of substitution between $\mathrm{G}$ and ordinary goods optimally to equal their price ratios results in $(\Sigma \partial \mathrm{U}(\bullet) / \partial \mathrm{G}) /(\partial \mathrm{U}(\bullet) / \partial \mathrm{X})=\mathrm{p}$.

Strictly rational optimizing individuals only equate their individual marginal value to the price: $(\partial \mathrm{U}(\bullet) / \partial \mathrm{G}) /(\partial \mathrm{U}(\bullet) / \partial \mathrm{X})=\mathrm{p}$. The marginal benefit level is set much too high ${ }^{2}$ with total consumption of $\mathrm{G}$ correspondingly set much too low. If there were only two non-cooperating individuals in society with similar preferences, $\mathrm{G}$ would be provided at about half of the socially-optimal level, and as the number of individuals gets larger, the difference between the social optimum and the observed provision level progressively increases.

The critical observation as we move into the next phase of the argument is not merely that provision levels of the public good, G, are likely to be very far from socially-optimal levels. This may or may not be the case, depending on numbers of individuals in the experiments, their familiarity with each other, and their expectations regarding the number of times the game will be played. What is important is that any time the public good is non-optimally supplied, each individual household will have high marginal values of the public good, in terms of leisure and private goods that they would be willing to give up to increase the public good. ${ }^{3}$ That is, each individual has an incentive to under-generate income ("buying" too much leisure). This provides another avenue of free-riding, an avenue that has not yet been explored in the public goods experiments in the literature (see Graves 2009, for further detail).

2

For the Cobb-Douglass, and similar utility functions that lack a "choke-price," there would be some small amount demanded by each individual, hence there would be some initial provision. In many realistic experiments with large numbers of anonymous individuals, the optimal quantity of the public good for each individual might be fairly close to zero.

3

To my knowledge, there are no public good experiments that address the income-generation free riding behavior of particular interest here. The experiments start with some fixed number of tokens that can be allocated between the private and public good, ignoring how much individuals might wish to increment work effort to increase the number of tokens available to buy the public good. 


\section{The Public Goods Experiments}

In typical public goods experiments, a group of $\mathrm{n}$ members decide simultaneously how much to invest in the public good, where the payoff for the ith person is given as:

2) $\mathrm{P}_{\mathrm{i}}=\mathrm{e}-\mathrm{g}_{\mathrm{i}}+\beta \Sigma_{\mathrm{n}} \mathrm{g}_{\mathrm{j}}$

where e $=$ initial endowment in "tokens," not varying across subjects,

$\mathrm{g}_{\mathrm{i}}=$ tokens subject $\mathrm{i}$ contributes to the group public good account,

$\beta=$ marginal payoff to each individual from the public good,

and $\Sigma_{\mathrm{n}} \mathrm{g}_{\mathrm{j}}=$ the sum of the $\mathrm{n}$ individual contributions to the public good.

As noted by Levitt and List (2007), by making $0<\beta<1<\mathrm{n} \beta$, a prisoner's dilemma situation is created in which each individual has an incentive to engage in free riding behavior that is against their collective best interest. As the cost of the public good, $\mathrm{g}_{\mathrm{i}}$, becomes smaller and as the marginal payoff, $\beta$, becomes larger, the extent of free riding would be expected to fall.

Typical findings, per Levitt and List, are that a "players contribution to public good is roughly $50 \%$ of endowment in one-shot games. Many players' contributions unravel to approach $0 \%$ in latter rounds of multi-period games." The Nash equilibrium for this game is frequently argued to be zero, but from the preceding section it is clear that if marginal values are high enough, homogeneous individuals will contribute some small amount, resulting is small, but positive, quantities of public goods provided. With heterogeneous subjects, actual contribution levels vary widely (see Jannsen and Ahn 2003), and a number of variants to the game have been concocted.

Of particular interest for present purposes is the ubiquitous finding that for a given level of average contribution in a round, there is a substantial variance in the level of contribution at the individual level. And this is despite each subject receiving identical initial endowments, which in the real-world would not be the case, as seen in Section II. Those who desire predominantly public goods would generate less income than those caring primarily for ordinary private goods.

The equi-marginal principle would suggest, ceteris paribus, that those exhibiting high pro-social values out of a fixed endowment would also generate more income by giving up leisure in real world settings. However, as public goods experiments are currently conducted, this possibility is not allowed. An alternative payoff for the ith person could be created as:

3) $\mathrm{P}_{\mathrm{i}}=\mathrm{e}_{0}+\mathrm{e}_{\mathrm{i}}(\mathrm{t})-\mathrm{g}_{\mathrm{i}}+\beta \Sigma_{\mathrm{n}} \mathrm{g}_{\mathrm{j}}$

where $e_{0}$ is an initial token endowment independent of work effort, $e_{i}(t)$ is the amount of tokens earned in some time-using activity (where $e_{i}$ would correspond to a subject's normal after tax wage), and the other variables are as previously defined. This modified experimental approach allows a richer and potentially more realistic 
set of behaviors to be observed than does the restriction in existing studies to identical initial token income.

\section{Conclusions}

Economic experiments in public goods provision are currently conducted by giving all subjects the same initial endowment and observing how contributions to the public good of interest change under varying circumstances. In the real-world, one would expect that those caring the most about public goods would generate the least income, so the imposition of initial endowment equality renders extrapolation of these experiments to an understanding of the real world problematic.

A recommendation would be to have a two-stage procedure in which subjects could earn tokens in a first stage to be used to contribute to the public good in a second stage. One might also design an experiment in which the decision of how many tokens to earn and how much to consume on the private and public good were simultaneously undertaken. With one of these modifications, a very pro-social individual would be expected to both earn more tokens in the first stage (or simultaneously) and contribute more tokens at the second stage (or simultaneously). A rational free-rider might generate little or no additional token income and might offer little of his or her non-earned endowment income for the public good.

It would be particularly interesting to examine how various subjects' work effort would change if they were told explicitly a) that working more at stage one would enable greater payments for the public good at stage two, versus b) that they could keep accumulated tokens as income available for private goods at the conclusion of the experiment regardless of their public good contribution.

\section{References}

Graves, P.E. 2009. A Note on the valuation of collective goods: Overlooked input market free riding for non-individually incrementable goods. The B.E. Journal of Economic Analysis and Policy, Vol. 9 : Iss. 1 (Topics).

Hanley, N., J.F. Shogren, and B. White 1997. Environmental economics in theory and practice. Oxford University Press: New York.

Jannsen, M.A. and T.K. Ahn 2006. Learning, signaling, and social preferences in public-good games. Ecology and Society 11(2): 21.

Levitt, S.D. and J.A. List 2007. What do laboratory experiments measuring social preferences reveal about the real world? Journal of Economic Perspectives 21 (2).

Varian, H.R. 1987. Intermediate microeconomics: A modern approach. W.W. Norton \& Company: New York. 


\section{CESifo Working Paper Series}

for full list see www.cesifo-group.org/wp

(address: Poschingerstr. 5, 81679 Munich, Germany, office@cesifo.de)

3124 Carlo V. Fiorio and Massimo Florio, A Fair Price for Energy? Ownership versus Market Opening in the EU15, July 2010

3125 Frederick van der Ploeg, Natural Resources: Curse or Blessing?, July 2010

3126 Kaisa Kotakorpi and Panu Poutvaara, Pay for Politicians and Candidate Selection: An Empirical Analysis, July 2010

3127 Jun-ichi Itaya, Makoto Okamura and Chikara Yamaguchi, Partial Tax Coordination in a Repeated Game Setting, July 2010

3128 Volker Meier and Helmut Rainer, On the Optimality of Joint Taxation for NonCooperative Couples, July 2010

3129 Ryan Oprea, Keith Henwood and Daniel Friedman, Separating the Hawks from the Doves: Evidence from Continuous Time Laboratory Games, July 2010

3130 Mari Rege and Ingeborg F. Solli, The Impact of Paternity Leave on Long-term Father Involvement, July 2010

3131 Olaf Posch, Risk Premia in General Equilibrium, July 2010

3132 John Komlos and Marek Brabec, The Trend of BMI Values by Centiles of US Adults, Birth Cohorts 1882-1986, July 2010

3133 Emin Karagözoğlu and Arno Riedl, Information, Uncertainty, and Subjective Entitlements in Bargaining, July 2010

3134 John Boyd, Gianni De Nicolò and Elena Loukoianova, Banking Crises and Crisis Dating: Theory and Evidence, July 2010

3135 Michael R. Baye, Dan Kovenock and Casper G. de Vries, The Herodotus Paradox, July 2010

3136 Martin Kolmar and Hendrik Rommeswinkel, Group Contests with Complementarities in Efforts, July 2010

3137 Carolina Manzano and Xavier Vives, Public and Private Learning from Prices, Strategic Substitutability and Complementarity, and Equilibrium Multiplicity, July 2010

3138 Axel Löffler, Gunther Schnabl and Franziska Schobert, Inflation Targeting by Debtor Central Banks in Emerging Market Economies, July 2010

3139 Yu-Fu Chen and Michael Funke, Global Warming and Extreme Events: Rethinking the Timing and Intensity of Environmental Policy, July 2010 
3140 Lawrence M. Kahn, Labor Market Policy: A Comparative View on the Costs and Benefits of Labor Market Flexibility, July 2010

3141 Ben J. Heijdra, Jochen O. Mierau and Laurie S.M. Reijnders, The Tragedy of Annuitization, July 2010

3142 Erkki Koskela, Outsourcing Cost and Tax Progression under Nash Wage Bargaining with Flexible Outsourcing, July 2010

3143 Daniel Osberghaus and Christiane Reif, Total Costs and Budgetary Effects of Adaptation to Climate Change: An Assessment for the European Union, August 2010

3144 Philip E. Graves, Benefit-Cost Analysis of Environmental Projects: A Plethora of Systematic Biases, August 2010

3145 Sabrina Di Addario and Daniela Vuri, Entrepreneurship and Market Size. The Case of Young College Graduates in Italy, August 2010

3146 Shoshana Amyra Grossbard and Alfredo Marvăo Pereira, Will Women Save more than Men? A Theoretical Model of Savings and Marriage, August 2010

3147 Jarko Fidrmuc, Time-Varying Exchange Rate Basket in China from 2005 to 2009, August 2010

3148 Ilja Neustadt and Peter Zweifel, Is the Welfare State Sustainable? Experimental Evidence on Citizens' Preferences for Redistribution, August 2010

3149 Marcus Dittrich and Andreas Knabe, Wage and Employment Effects of Non-Binding Minimum Wages, August 2010

3150 Shutao Cao, Enchuan Shao and Pedro Silos, Fixed-Term and Permanent Employment Contracts: Theory and Evidence, August 2010

3151 Ludger Woessmann, Cross-Country Evidence on Teacher Performance Pay, August 2010

3152 Lorenzo C. G. Pozzi, Casper G. de Vries and Jorn Zenhorst, World Equity Premium Based Risk Aversion Estimates, August 2010

3153 Volker Grossmann, Thomas M. Steger and Timo Trimborn, Dynamically Optimal R\&D Subsidization, August 2010

3154 Alexander Haupt, Tim Krieger and Thomas Lange, A Note on Brain Gain and Brain Drain: Permanent Migration and Education Policy, August 2010

3155 António Afonso and Christophe Rault, Long-run Determinants of Sovereign Yields, August 2010

3156 Franziska Tausch, Jan Potters and Arno Riedl, Preferences for Redistribution and Pensions. What can we Learn from Experiments?, August 2010 
3157 Martin Kolmar and Andreas Wagener, Inefficient Group Organization as Optimal Adaption to Dominant Environments, August 2010

3158 Kai Carstensen, Klaus Wohlrabe and Christina Ziegler, Predictive Ability of Business Cycle Indicators under Test: A Case Study for the Euro Area Industrial Production, August 2010

3159 Horst Rottmann and Timo Wollmershäuser, A Micro Data Approach to the Identification of Credit Crunches, August 2010

3160 Philip E. Graves, Appropriate Fiscal Policy over the Business Cycle: Proper Stimulus Policies Can Work, August 2010

3161 Michael Binder and Marcel Bluhm, On the Conditional Effects of IMF Program Participation on Output Growth, August 2010

3162 Michael Binder, Qianying Chen, and Xuan Zhang, On the Effects of Monetary Policy Shocks on Exchange Rates, August 2010

3163 Felix J. Bierbrauer, On the Optimality of Optimal Income Taxation, August 2010

3164 Nikolaus Wolf, Europe's Great Depression - Coordination Failure after the First World War, September 2010

3165 Dan Kovenock and Brian Roberson, Conflicts with Multiple Battlefields, September 2010

3166 Jean-Pierre Ponssard and Catherine Thomas, Capacity Investment under Demand Uncertainty. An Empirical Study of the US Cement Industry, 1994-2006, September 2010

3167 Jørgen Juel Andersen, Jon H. Fiva and Gisle James Natvik, Voting when the Stakes are High, September 2010

3168 Michael Hoel, Is there a Green Paradox?, September 2010

3169 Scott Alan Carson, Nineteenth Century US African-American and White Female Statures: Insight from US Prison Records, September 2010

3170 Gil S. Epstein, Yosef Mealem and Shmuel Nitzan, Political Culture and Discrimination in Contests, September 2010

3171 Sara Fisher Ellison, Jeffrey Greenbaum and Wallace P. Mullin, Diversity, Social Goods Provision, and Performance in the Firm, September 2010

3172 Silvia Dominguez-Martinez, Randolph Sloof and Ferdinand von Siemens, Monitoring your Friends, not your Foes: Strategic Ignorance and the Delegation of Real Authority, September 2010 
3173 Marcus Dittrich and Beate Schirwitz, Union Membership and Employment Dynamics: A Note, September 2010

3174 Francesco Daveri, Paolo Manasse and Danila Serra, The Twin Effects of Globalization - Evidence from a Sample of Indian Manufacturing Firms, September 2010

3175 Florian Blöchl, Fabian J. Theis, Fernando Vega-Redondo and Eric O'N. Fisher, Which Sectors of a Modern Economy are most Central?, September 2010

3176 Dag Morten Dalen, Marilena Locatelli and Steinar Strøm, Longitudinal Analysis of Generic Substitution, September 2010

3177 Armin Falk, Stephan Meier and Christian Zehnder, Did we Overestimate the Role of Social Preferences? The Case of Self-Selected Student Samples, September 2010

3178 Christian Fahrholz and Cezary Wójcik, The Bail-Out! Positive Political Economics of Greek-type Crises in the EMU, September 2010

3179 Klaus Abberger and Wolfgang Nierhaus, The Ifo Business Cycle Clock: Circular Correlation with the Real GDP, September 2010

3180 Walter Krämer and Gerhard Arminger, "True Believers" or Numerical Terrorism at the Nuclear Power Plant, September 2010

3181 Bernard M.S. Van Praag, Dmitri Romanov and Ada Ferrer-i-Carbonell, Happiness and Financial Satisfaction in Israel. Effects of Religiosity, Ethnicity, and War, September 2010

3182 Dimitrios Koumparoulis and Paul De Grauwe, Public Capital, Employment and Productivity: An Empirical Investigation for Greece, September 2010

3183 John Whalley and Tanmaya Shekhar, The Rapidly Deepening India-China Economic Relationship, September 2010

3184 Andreas Schäfer and Thomas Steger, History, Expectations, and Public Policy: Economic Development in Eastern Germany, September 2010

3185 Thomas Eichner and Marco Runkel, Subsidizing Renewable Energy under Capital Mobility, September 2010

3186 Konstantinos Angelopoulos and James Malley, Fear of Model Misspecification and the Robustness Premium, September 2010

3187 Philip E. Graves, A Note on the Design of Experiments Involving Public Goods, September 2010 